\title{
ANALISIS DAN PERBANDINGAN JENIS KAWAT KANTHAL A-1 DAN NICHROME 80 SEBAGAI ELEMEN PEMANAS PADA OVEN LISTRIK HEMAT ENERGI
}

\author{
Victorius Veinard Vingtsabta ${ }^{*}$, Abdul Syakur dan Agung Warsito \\ Departemen Teknik Elektro, Universitas Diponegoro \\ Jl. Prof. Sudharto, SH, Kampus UNDIP Tembalang, Semarang 50275, Indonesia \\ ${ }^{*}$ E-mail: vingtsabta@gmail.com
}

\begin{abstract}
Abstrak
Pada era ini kita membutuhkan peralatan elektronik yang hemat dan efisien, contohnya oven. Dalam oven terdapat elemen pemanas. Elemen pemanas yang digunakan harus menghasilkan panas yang optimum dan hemat energi. Elemen pemanas yang digunakan dalam penelitian ini yaitu $\mathrm{FeCrAl}$ alloy and $\mathrm{NiCrSi}$ alloy. $\mathrm{FeCrAl}$ alloy atau kawat Kanthal A-1 tersusun atas 20\% kromium, 5,8\% aluminium dan besi, sedangkan NiCrSi atau Nichrome 80 tersusun atas $80 \%$ nikel, 19,5\% kromium dan 1,45\% silicon. Digunakannya kedua bahan tersebut karena kedua bahan tersebut memiliki nilai resitansi yang rendah dan dapat menghasilkan panas yang tinggi. Dalam penelitian ini menggunakan Kawat Nichrome 80 dan Kanthal A-1 berdiameter kawat $0,8 \mathrm{~mm}$ dan $1 \mathrm{~mm}$ dengan variasi lilitan $8 \mathrm{~mm}, 10 \mathrm{~mm}$ dan $12 \mathrm{~mm}$. Kedua kawat tersebut diaplikasikan dalam pemanas oven berukuran $40 \mathrm{cmx} 40 \mathrm{~cm}$ x $50 \mathrm{~cm}$. Didapatkan kawat Nichrome berdiameter kawat 1 $\mathrm{mm}$ dengan diameter lilitan $8 \mathrm{~mm}$ menghasilkan suhu maksimal $76,17{ }^{\circ} \mathrm{C}$ dengan waktu 60 menit. Daya terendah dikonsumsi yaitu $170 \mathrm{~W}$ oleh kawat Nichrome 80 (diameter kawat $0,8 \mathrm{~mm}$ dengan diameter lilitan $10 \mathrm{~mm}$ ). Sedangkan energi terendah yang dikonsumsi yaitu 10,45 Wh oleh Kawat Nichrome $1 \mathrm{~mm}$ dengan diameter lilitan $8 \mathrm{~mm}$. Dapat simpulkan bahwa diameter kawat dan jenis kawat memengaruhi nilai resistansi. Nilai resistansi memengaruhi arus, daya dan energi yang digunakan.
\end{abstract}

Kata kunci: Kawat Nichrome 80, Kawat Kanthal A-1, elemen pemanas, resistansi, konsumsi energi

\begin{abstract}
In this era we need efficient electronic equipment, for example ovens. In the oven there is a heating element. The heating element used must produce optimum heat and save energy. The heating elements used in this Final Project are $\mathrm{FeCrAl}$ alloy and $\mathrm{NiCrSi}$ alloy. FeCrAl Alloy or wire Kanthal A-1 is composed of $20 \%$ chromium, $5.8 \%$ aluminum and iron, while $\mathrm{NiCrSi}$ or Nichrome 80 is composed of $80 \%$ nickel, $19.5 \%$ chromium and $1.45 \%$ silicon. The use of these two wire is because both materials have low resitance values and can produce high heat. In this Final Project uses Nichrome 80 Wire and Kanthal A-1 wire with a diameter of $0.8 \mathrm{~mm}$ and $1 \mathrm{~mm}$ with winding variations of $8 \mathrm{~mm}, 10 \mathrm{~mm}$ and $12 \mathrm{~mm}$. The two wires were applied in an oven dimension $40 \mathrm{~cm}$ x $40 \mathrm{~cm} \times 50 \mathrm{~cm}$. Nichrome wire with $1 \mathrm{~mm}$ wire diameter and $8 \mathrm{~mm}$ winding diameter produces a maximum temperature of $76.17^{\circ} \mathrm{C}$ with 60 minutes. The lowest power consumed is $170 \mathrm{~W}$ by Nichrome 80 wire $(0.8 \mathrm{~mm}$ wire diameter with $10 \mathrm{~mm}$ winding diameter). Whereas the lowest energy consumed is $10.45 \mathrm{Wh}$ by Nichrome Wire $1 \mathrm{~mm}$ with a winding diameter of $8 \mathrm{~mm}$. It can be concluded that the wire diameter and type of wire affect the resistance value. The resistance value affects the current, power and energy used.
\end{abstract}

Keywords: Nichrome 80 wire, Kanthal A-1 wire, heating element, resistance, energy consumption

\section{Pendahuluan}

Kebutuhan hidup manusia pada saat ini semakin kompleks, sehingga untuk membantu kehidupan sehari-hari diperlukan teknologi yang praktis, murah dan aman. Kemajuan teknologi ini tentunya tidak hanya bertujuan untuk teknologi itu sendiri melainkan yang lebih penting adalah untuk kesejahteraan manusia. Salah satunya pemanfaatannya adalah dalam bidang industri. Pada salah satu industri yaitu proses pemanggangan ikan. Maka diperlukan suatu alat pemanggang (oven) yang bersifat aman, hemat dan ramah lingkungan [1]. Dalam pemanggang ikan (oven) tersebut digunakan pemanas (heater) untuk memanggang ikan, pemanas (heater) yang digunakan bervariasi [2].

Oven adalah alat yang digunakan untuk mengeringkan suatu bahan basah menjadi bahan kering agar dapat disimpan dalam jangka waktu yang lama. Proses pengeringan dengan oven menggunakan media yang dapat 
menampung suhu panas secara konstan. Oven pada umumnya menggunakan pemanas (heater) sebagai penghasil pemanas [3][4].

Sebagai sumber panas yang dihasilkan oleh elemen pemanas listrik bersumber dari kawat ataupun pita bertahanan listrik tinggi (resistance wire) biasanya bahan yang digunakan adalah kawat Niklin yang digulung menyerupai bentuk spiral dan dimasukkan dalam selongsong/pipa sebagai pelindung, kemudian dialiri arus listrik pada kedua ujungnya dan dilapisi oleh isolator listrik yang mampu meneruskan panas dengan baik hingga aman digunakan. Bentuk dan tipe dari electrical heating element ini bermacam-macam disesuaikan dengan fungsi tempat pemasangan [5][6].

Kawat penghantar yang digunakan untuk penelitian ini yaitu berjenis Kanthal A-1 dan Nichrome 80/Ni 80. Kawat Kanthal A-1 mengandung campuran terdiri dari $20 \%$ kromium, 5,8 aluminium dan besi [7] dan kawat Nichrome 80/Ni 80 mengandung logam campuran $80 \%$ nikel, $19,5 \%$ kromium dan 1,45 silikon [8]. Alasan menggunakan kawat penghantar Kanthal A-1 dan Nichrome 80, karena kedua kawat tersebut memiliki resistansi rendah, sehingga dapat menghasilkan panas yang tinggi.

Penelitian ini dilakukan untuk mendapatkan metode terbaik dalam pemanasan yang efektif dan efisien. Melalui analisis elektrik bahan sehingga diketahui jenis kawat yang efektif dan efisien, sehingga menghasilkan panas yang optimum. Untuk lebih lanjutnya kawat penghantar manakah yang cocok untuk pemanas (heater) yang hemat energi.

\section{Metode}

\subsection{Prosedur Penelitian}

Pada penelitian ini menggunakan 4 metode, yaitu pengukuran, resistansi, pengukuran arus, pengukuran daya dan pengukuran suhu. Keempat metode tersebut memiliki tahapan penelitian seperti pada gambar 1 .

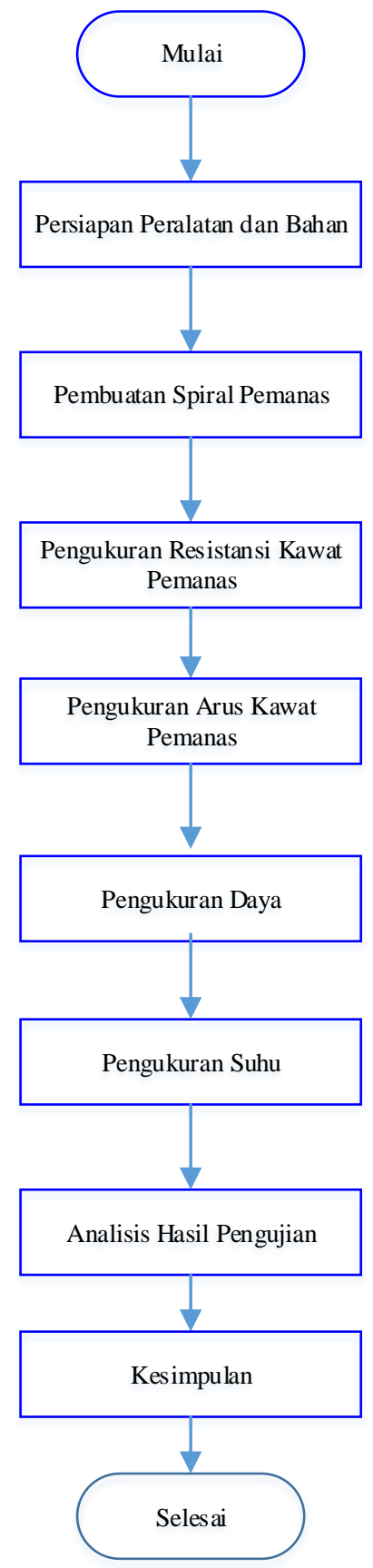

Gambar 1. Prosedur penelitian 


\subsection{Pembuatan Sampel Uji}

Pembuatan sampel uji dengan kawat Kanthal A-1 dan Nichrome 80 sepanjang 10 meter berdiameter kawat 0,8 $\mathrm{mm}$ dan $1 \mathrm{~mm}$ dengan variasi lilitan $8 \mathrm{~mm}, 10 \mathrm{~mm}$ dan 12 $\mathrm{mm}$.

Tabel 1. Sampel uji

\begin{tabular}{ccc}
\hline Jenis Kawat & $\begin{array}{c}\text { Diameter } \\
\text { kawat }(\mathrm{mm})\end{array}$ & $\begin{array}{c}\text { Diameter Lilitan } \\
(\mathrm{mm})\end{array}$ \\
\hline & & 8 \\
Kanthal A-1 & 0,8 & 10 \\
& & 12 \\
& 1 & 8 \\
& & 10 \\
Nichrome 80 & 0,8 & 12 \\
& & 10 \\
& 1 & 12 \\
& 1 & 10 \\
& & 12 \\
\hline
\end{tabular}

\subsection{Pengukuran Resistansi}

Pengukuran resistansi menggunakan LCR meter

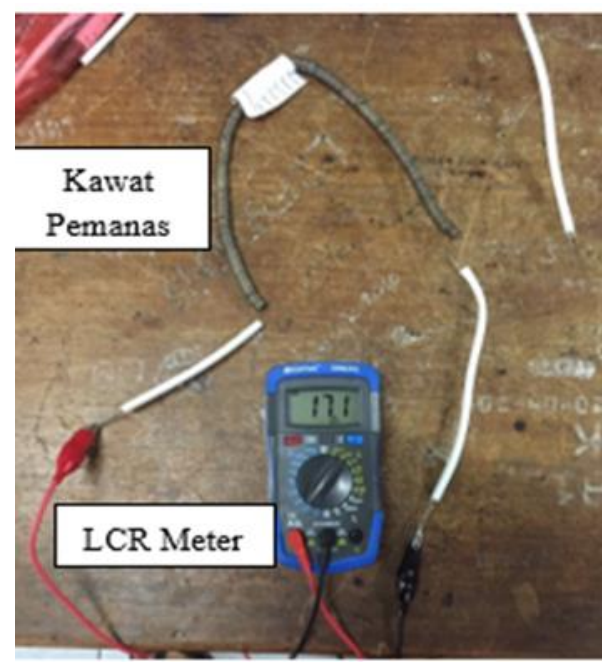

Gambar 2. Pengukuran resistansi

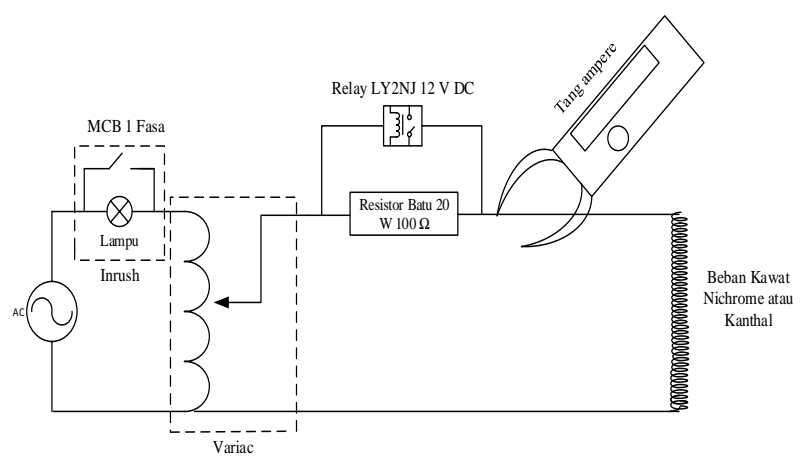

Gambar 3. Rangkaian pengukuran arus

\subsection{Pengukuran daya}

Pengukuran daya menggunakan power quality analyzer

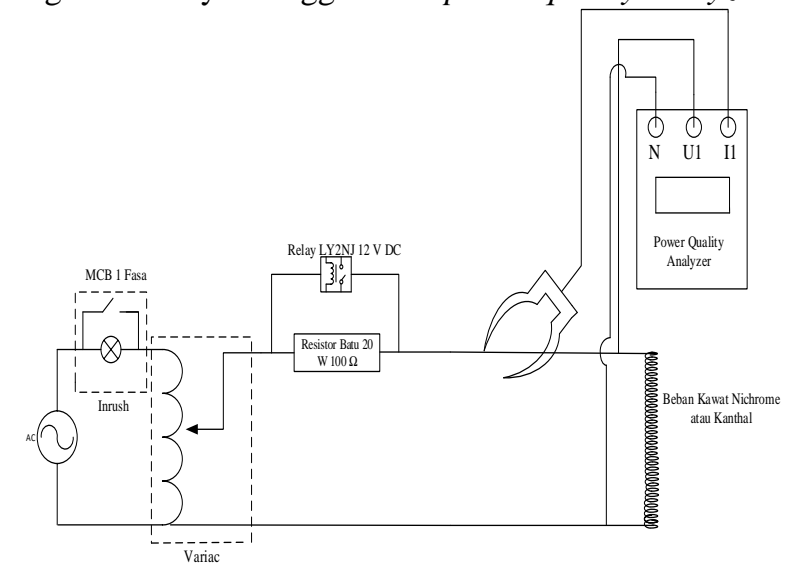

Gambar 4. Rangkaian pengukuran daya

\subsection{Pengukuran Suhu}

Pengukuran suhu menggunakan thermocouple yang dihubungkan ke arduino

\subsection{Pengukuran Arus}

Pengukuran arus menggunakan tang ampere 


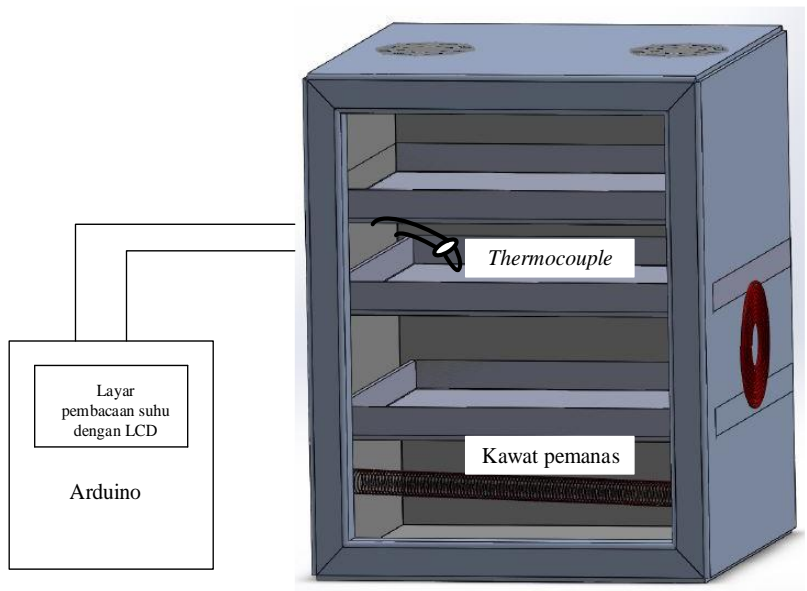

Gambar 5. Pengukuran suhu

\section{Hasil dan Analisis}

\subsection{Pengujian Kawat Kanthal A-1}

Berdasarkan pengujian kawat Kanthal A-1 dapat didapatkan beberapa parameter yaitu :

\subsubsection{Suhu}

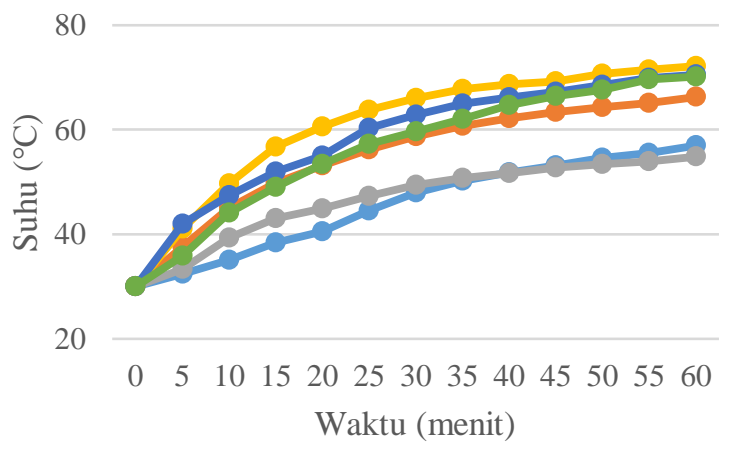

Gambar 6. Grafik pengaruh suhu terhadap waktu kawat Kanthal A-1 diameter kawat 0,8 mm dan 1 mm

Berdasarkan hasil pengujian ditunjukkan bahwa dengan semakin lama waktu pemanasan maka suhu yang dihasilkan akan mengalami kenaikan, hal ini disebabkan karena adanya arus listrik yang mengalir dalam sebuah kawat penghantar yang ditimbulkan oleh gerakan muatan elektron

Variasi diameter kawat memengaruhi suhu yang dihasilkan oleh kawat pemanas, karena semakin besar diameter kawat (luas penampang), maka semakin kecil resistansinya. Dalam Hukum Ohm, nilai resistansi (hambatan) dan arus berbanding terbalik. Jika resistansi suatu kawat kecil maka arus yang mengalir besar. Arus yang menyebabkan panas pada kawat pemanas

\subsubsection{Daya rata-rata}

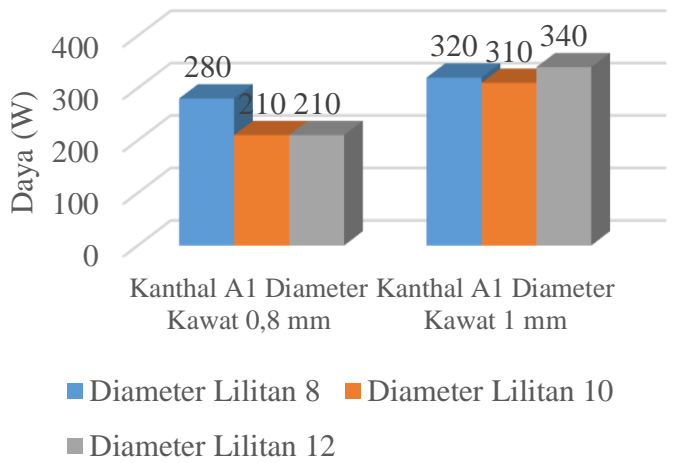

Gambar 7. Perbandingan daya rata-rata kawat Kanthal A-1 diameter $0,8 \mathrm{~mm}$ dan $1 \mathrm{~mm}$

Pengaruh diameter kawat berpengaruh terhadap daya yang digunakan. Semakin besar luas penampang (diameter kawat), maka resistansinya semakin kecil. Dalam Hukum Ohm, nilai arus dan resistansi berbanding terbalik, jika nilai resistansinya kecil, maka nilai arusnya besar. Sedangkan daya yang dikonsumsi berbanding lurus dengan arus yang dihasilkan. Sehingga daya yang dikonsumsi kawat Kanthal A-1 berdiameter kawat $1 \mathrm{~mm}$ lebih besar dibandingkan kawat Kanthal A-1 berdiameter kawat 0,8 mm, karena nilai resistansi kawat Kanthal A-1 diameter kawat $1 \mathrm{~mm}$ lebih kecil kecil dibanding kawat Kanthal A1 berdiameter kawat $0,8 \mathrm{~mm}$.

\subsubsection{Energi}

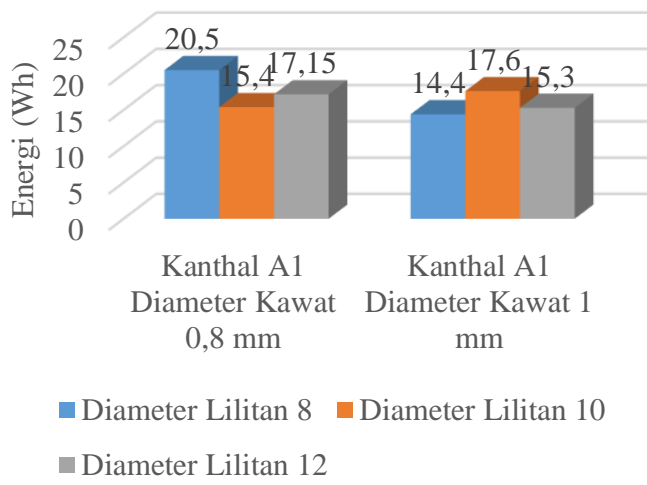

Gambar 8. Perbandingan konsumsi energi kawat Kanthal A-1 diameter $0,8 \mathrm{~mm}$ dan $1 \mathrm{~mm}$

Konsumsi energi terendah untuk menghasilkan suhu $40{ }^{\circ} \mathrm{C}$ yaitu kawat Kanthal A-1 (diameter kawat $1 \mathrm{~mm}$ ) dengan diameter lilitan $8 \mathrm{~mm}$ yaitu 14,4 Wh. Sedangkan konsumsi energi terbesar untuk menghasilkan suhu $40^{\circ} \mathrm{C}$ yaitu kawat 
Kanthal A-1 (diameter kawat $0,8 \mathrm{~mm}$ ) dengan diameter lilitan $8 \mathrm{~mm}$ yaitu 20,5 Wh.

\subsection{Pengujian Kawat Nichrome 80}

\subsubsection{Suhu}
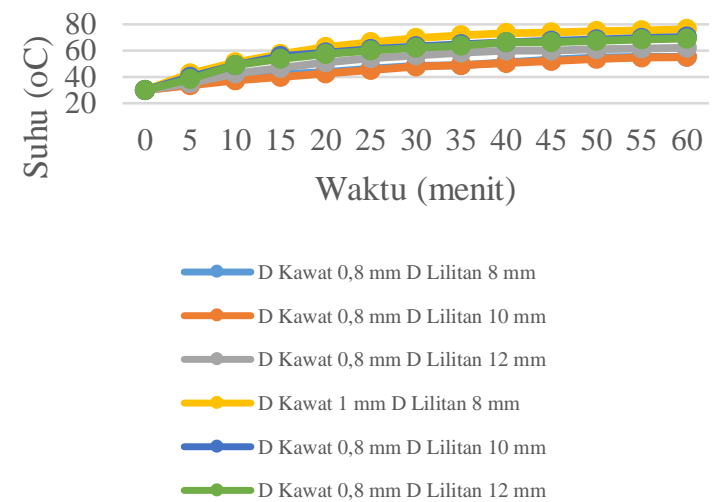

Gambar 9. Grafik pengaruh suhu terhadap waktu kawat Nichrome diameter kawat $0,8 \mathrm{~mm}$ dan $1 \mathrm{~mm}$

Berdasarkan hasil pengujian ditunjukkan bahwa dengan semakin lama waktu pemanasan maka suhu yang dihasilkan akan mengalami kenaikan, hal ini disebabkan karena adanya arus listrik yang mengalir dalam sebuah kawat penghantar yang ditimbulkan oleh gerakan muatan elektron

Variasi diameter kawat memengaruhi suhu yang dihasilkan oleh kawat pemanas, karena semakin besar diameter kawat (luas penampang), maka semakin kecil resistansinya. Dalam Hukum Ohm, nilai resistansi (hambatan) dan arus berbanding terbalik. Jika resistansi suatu kawat kecil maka arus yang mengalir besar. Arus yang menyebabkan panas pada kawat pemanas

\subsubsection{Daya rata-rata}

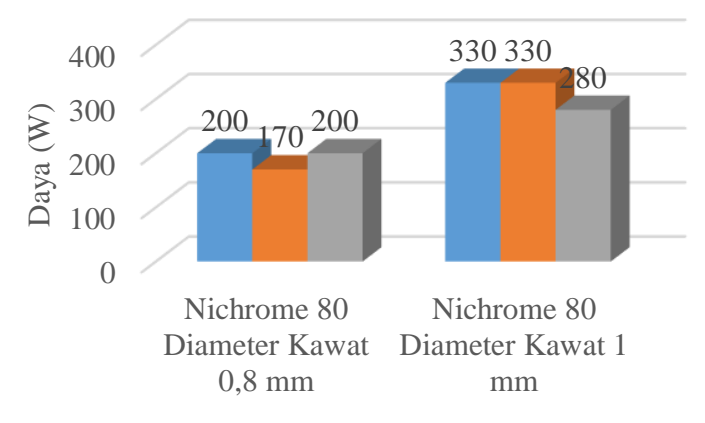

- Diameter Lilitan 8 a Diameter Lilitan 10

- Diameter Lilitan 12

Gambar 10. Perbandingan daya rata-rata kawat Nichrome 80 diameter $0,8 \mathrm{~mm}$ dan $1 \mathrm{~mm}$
Pengaruh diameter kawat berpengaruh terhadap daya yang dikonsumsi. Semakin besar luas penampang (diameter kawat), maka resistansinya semakin kecil. Dalam Hukum Ohm, nilai arus dan resistansi berbanding terbalik, jika nilai resistansinya kecil, maka nilai arusnya besar Sedangkan daya yang dikonsumsi berbanding lurus dengan arus yang dihasilkan. Sehingga daya yang dikonsumsi kawat Nichrome 80 berdiameter kawat $1 \mathrm{~mm}$ lebih besar dibandingkan kawat Nichrome 80 berdiameter kawat 0,8 $\mathrm{mm}$, karena nilai resistansi kawat Nichrome diameter kawat $1 \mathrm{~mm}$ lebih kecil kecil dibanding kawat Nichrome berdiameter kawat $0,8 \mathrm{~mm}$.

\subsubsection{Energi}

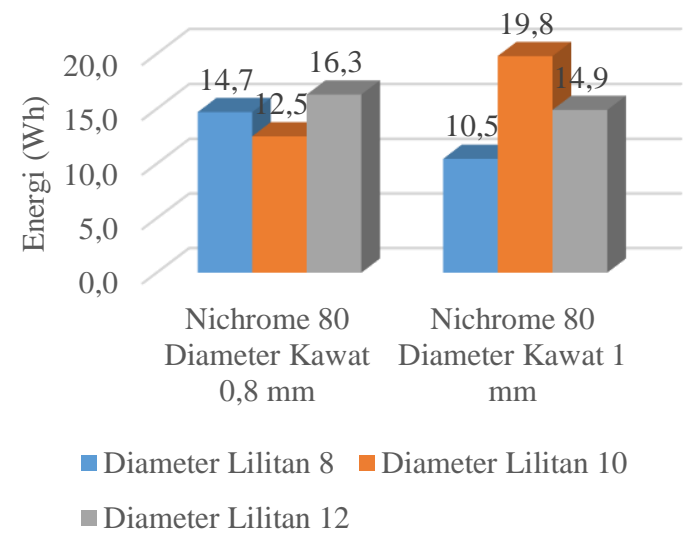

Gambar 11. Perbandingan konsumsi energi kawat Nichrome 80 diameter $0,8 \mathrm{~mm}$ dan $1 \mathrm{~mm}$

Konsumsi energi terendah yang digunakan untuk menghasilkan suhu $40{ }^{\circ} \mathrm{C}$ yaitu kawat Nichrome 80 (diameter kawat $1 \mathrm{~mm}$ ) dengan diameter lilitan $8 \mathrm{~mm}$ yaitu 10,5 Wh. Sedangkan daya terbesar untuk menghasilkan suhu $40{ }^{\circ} \mathrm{C}$ yaitu kawat Nichrome 80 (diameter kawat 1 $\mathrm{mm}$ ) dengan diameter lilitan 10 yaitu $19,8 \mathrm{Wh}$.

\subsection{Perbandingan Kawat Kanthal A-1 dan Nichrome 80 \\ 3.3.1. Suhu}

Pada pengukuran suhu diperoleh data adanya pengaruh variasi diameter kawat dan jenis kawat terhadap suhu yang dihasilkan pada kawat Kanthal A-1 dan Nichrome 80. Suhu tertinggi dihasilkan oleh kawat Nichrome (diameter lilitan $1 \mathrm{~mm}$ ) dengan diameter lilitan $8 \mathrm{~mm}$, sedangkan suhu terendah dihasilkan oleh kawat Nichrome (diameter lilitan $0,8 \mathrm{~mm}$ ) dengan diameter lilitan $10 \mathrm{~mm}$. Suhu yang dihasilkan kawat Nichrome 80 (diameter kawat $1 \mathrm{~mm}$ ) dengan diameter lilitan $8 \mathrm{~mm}$ yaitu $76,17^{\circ} \mathrm{C}$, sedangkan suhu yang dihasilkan kawat Kanthal A-1 (diameter kawat $0,8 \mathrm{~mm}$ ) dengan diameter lilitan $10 \mathrm{~mm}$ yaitu $55,04{ }^{\circ} \mathrm{C}$.

Kawat Nichrome 80 menghasilkan panas lebih daripada kawat Kantal A-1 karena nilai resistansi kawat Nichrome 80 lebih kecil bandingkan kawat Kanthal A-1. Nilai 
resistansi kawat Nichrome diameter kawat $1 \mathrm{~mm}$ yaitu $0,012 \Omega / \mathrm{m}$ dan diameter kawat $0,8 \mathrm{~mm}$ memiliki resistansi yaitu $0,019 \Omega / \mathrm{m}$, kemudian nilai resistansi kawat Kanthal A-1 diameter kawat $1 \mathrm{~mm}$ yaitu $0,016 \Omega / \mathrm{m}$ dan untuk diameter kawat $0,8 \mathrm{~mm}$ yaitu $0,025 \Omega / \mathrm{m}$. Sehingga dapat dilihat diameter kawat (luas penampang) memengaruhi nilai resistansi, karena nilai resitansi berbanding terbalik dengan luas penampang. Sehingga jika luas penampang kawat makin besar, nilai resistansinya makin kecil. Dalam Hukum Ohm nilai arus dan resistansi berbanding terbalik. Semakin kecil nilai resistansinya, maka nilai arusnya semakin besar. Panas yang dihasilkan oleh kawat pemanas disebabkan oleh arus. Arus yang mengalir pada kawat pemanas disebabkan karena gerakan elektron-elektron bebas yang bertumbukan pada kawat pemanas.
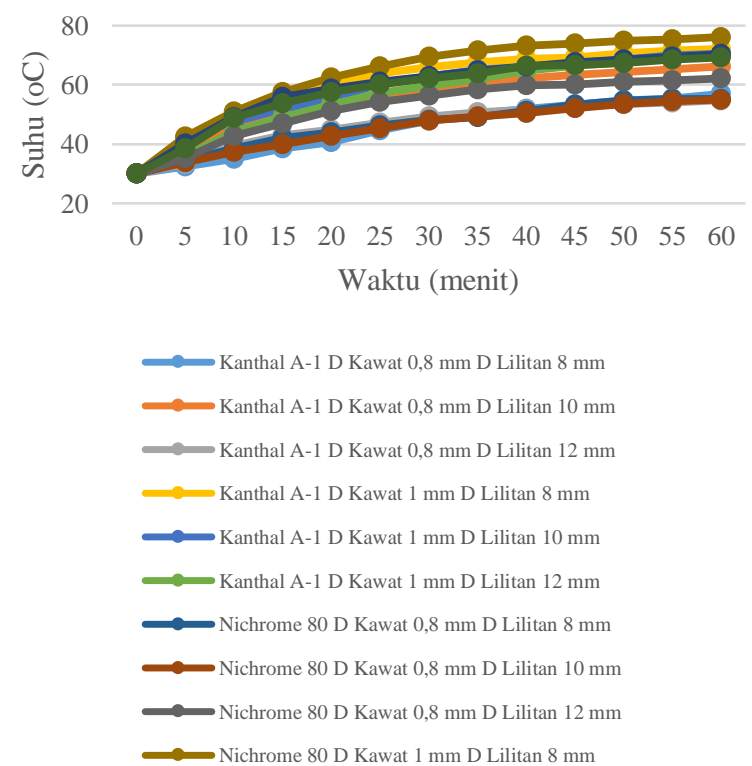

Gambar 12. Perbandingan suhu terhadap waktu kawat Kanthal A-1 dan Nichrome 80

\subsubsection{Daya rata-rata}

Daya rata-rata yang dihasilkan selama 60 menit, daya ratarata terendah dihasilkan oleh kawat Nichrome 80 (diameter kawat $0,8 \mathrm{~mm}$ ) dengan diameter lilitan $10 \mathrm{~mm}$. Sedangkan daya rata-rata terbesar yang selama 60 menit yaitu kawat Nichrome 80 (diameter kawat $1 \mathrm{~mm}$ ) dengan diameter lilitan $8 \mathrm{~mm}$ dan $10 \mathrm{~mm}$.

Kawat Nichrome 80 (diameter kawat $0,8 \mathrm{~mm}$ ) dengan diameter lilitan $10 \mathrm{~mm}$ menghasilkan daya selama 60 menit yaitu $170 \mathrm{~W}$. Untuk kawat Nichrome 80 (diameter kawat 1 $\mathrm{mm}$ ) dengan diameter lilitan $8 \mathrm{~mm}$ dan $10 \mathrm{~mm}$ menghasilkan daya sebesar $330 \mathrm{~W}$ selama 60 menit.

Dapat disimpulkan bahwa pengaruh jenis kawat berpengaruh terhadap daya yang dikonsumsi. Jenis kawat memiliki nilai resistansi yang berbeda-beda. Dalam Hukum Ohm, nilai arus dan resistansi berbanding terbalik, jika nilai resistansinya kecil, maka nilai arusnya besar. Sedangkan daya yang dikonsumsi berbanding lurus dengan arus yang dihasilkan. Sehingga daya yang dikonsumsi kawat Nichrome 80 lebih besar daripada kawat Kanthal A1. Namun akibat kesalahan dalam pembuatan nilai daya yang dihasilkan belum sesuai teori.

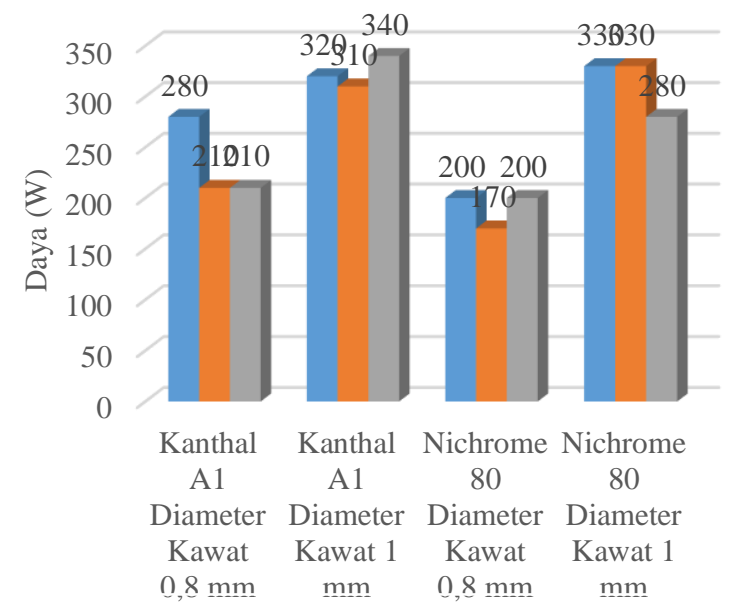

口 Diameter Lilitan 8 Diameter Lilitan 10

- Diameter Lilitan 12

Gambar 12. Perbandingan daya rata-rata kawat Kanthal A1 dan Nichrome 80

\subsubsection{Energi}

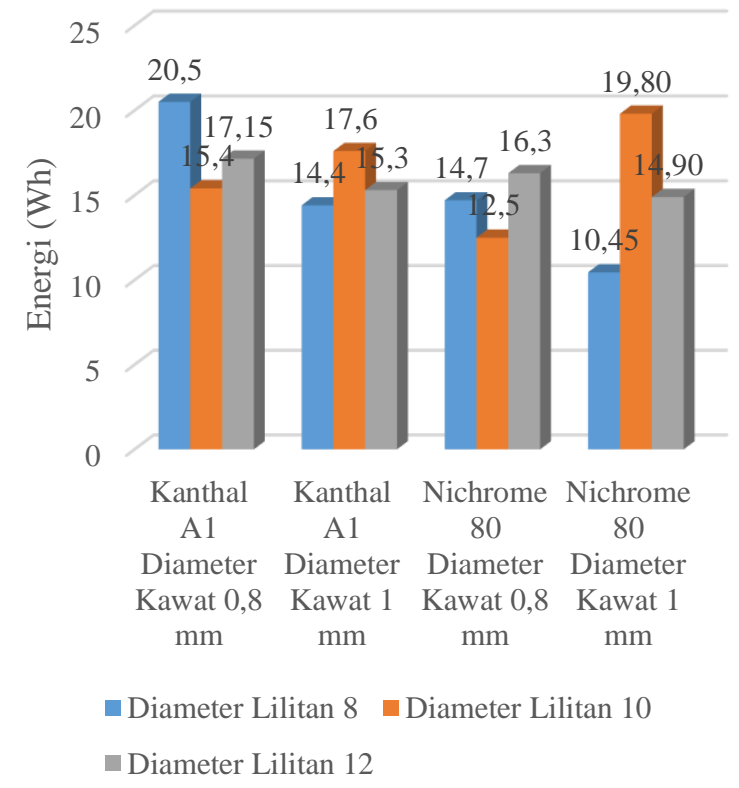

Gambar 13. Perbandingan konsumsi energi kawat Kanthal A-1 dan Nichrome 80 
Konsumsi energi yang digunakan untuk menghasilkan suhu $40^{\circ} \mathrm{C}$, konsumsi energi terendah dihasilkan oleh kawat Nichrome 80 (diameter kawat $1 \mathrm{~mm}$ ) dengan diameter lilitan $8 \mathrm{~mm}$ yaitu $10,45 \mathrm{Wh}$. Sedangkan konsumsi energi terbesar yang digunakan untuk menghasilkan suhu $40^{\circ} \mathrm{C}$ yaitu kawat Kanthal A-1 (diameter kawat $0,8 \mathrm{~mm}$ ) dengan diameter lilitan $8 \mathrm{~mm}$ yaitu $20,5 \mathrm{Wh}$.

Konsumsi energi dipengaruhi oleh waktu dan juga daya yang digunakan. Nilai daya dipengaruhi oleh arus. Nilai arus dipengaruhi oleh resistansi, kemudian nilai resistansi dipengaruhi oleh nilai luas penampang dan jenis kawat. Jadi besar luas penampang/diameter lilitan dan jenis kawat memengaruhi nilai konsumsi energi. Nilai resitansi kawat Nichrome 80 lebih besar dibanding kawat Kanthal A-1, sehingga arus yang mengalir besar. Arus yang besar akan memengaruhi nilai daya yang digunakan. Sehingga jika arus besar dan tegangan konstan, maka daya yang dihasilkan besar, semakin besar daya yang dihasilkan maka memerlukan waktu yang cepat untuk mencapai suhu $40^{\circ} \mathrm{C}$. Sehingga dapat diketahu bahwa nilai resistansi berpengaruh pada nilai konsumsi energi

\section{Kesimpulan}

Berdasarkan hasil dan analisis yang telah dilakukan maka dapat dibuat kesimpulan resistansi dan jenis kawat berpengaruh pada nilai arus, suhu yang dihasilkan, daya yang digunakan dan konsumsi energi. Kawat Nichrome 80 memiliki nilai resistansi lebih kecil dibanding kawat Kanthal A-1. Nilai resistansi berpengaruh terhadap arus, karena dalam Hukum Ohm nilai arus dan resistansi berbanding terbalik. Apabila nilai resistansinya rendah maka arusnya tinggi. Arus tinggi menyebabkan panas yang dihasilkan semakin tinggi. Hal tersebut akibat adanya tumbukan antar elektron yang semakin kuat. Nilai resistansi memengaruhi daya karena daya berbanding lurus dengan resistansi. Nilai resistansi memengaruhi konsumsi energi, energi dengan resistansi berbanding lurus. Jadi dapat disimpukan bahwa kawat Nichrome 80 lebih cocok dijadikan kawat pemanas, karena nilai resistansinya lebih rendah dibanding kawat Kanthal A-1, sehingga menghasilkan panas yang optimum, daya yang rendah dan konsumsi daya rendah.

\section{Referensi}

[1] A. Nurhidayat, T. Mesin, U. Surakarta, K. Surakarta, and J. Barat, "Rekayasa Alat Pengering Untuk Meningkatan Produktivitas Ukm Emping Mlinjo," Semin. Nas. Sains dan Teknol., pp. 37-41, 2010.

[2] A. S. I. Akbar, "Rancang Bangun Prototype Sistem Pemanggang Kue ( Oven ) Otomatis Dengan Menggunakan Mikrokontroler Avr Atmega 8535," Dielektrika, vol. 1, no. 2, pp. 69-81, 2014.

[3] M. R. Rahmat, "Perancangan Dan Pembuatan Tungku Heat Treatment," J. Ilm. Tek. Mesin, vol. 3, no. 2, pp. 133-148, 2015

[4] F. B. Setiawan, M. Rizqiyanto, J. Umbu, and M. Yiwa, "Oven Terprogram Berbasis ikrokontroler," Widya Tek., vol. 21, no. 2, pp. 10-14, 2013.

[5] R. Triandi, "ANALISIS PENGARUH TEMPERATUR TERHADAP PENGHANTAR LISTRIK NFA2X 2x10mm rm 0.6/1kV SKRIPSI," Tugas Akhir, 2010.

[6] D. Wulandari, "Perancangan Sistem Pemanas Pada Rancang Bangun Mesin Pengaduk Bahan Baku Sabun Mandi Cair" JRM, vol. 1, no. 2, pp. 52-57, 2014.

[7] "Data Sheet Kanthal A-1," no. 510, pp. 1-3.

[8] "Data Sheet Nichrome 80," vol. 80, no. 510. 